\title{
Televizyon Reklamlarında Ünlü Kullanımının Tüketiciler Açısından Değerlendirilmesi: Uşak Üniversitesi İletişim Fakültesi Öğrencilerine Yönelik Bir Araştırma
}

\author{
Murat Sezgin* \\ Uşak Üniversitesi \\ İletişim Fakültesi \\ orcid.org/0000-0003-2200-3301
}

\author{
Ercan Yilmaz \\ Uşak Üniversitesi \\ Halkla İlişkiler Yüksek Lisans Öğrencisi \\ orcid.org/0000-0003-4691-9373
}

Gönderilme Tarihi

12.09.2019

$\underline{\text { Kabul Tarihi }}$

12.09.2019

\section{$\ddot{O} z$}

Firmalar, uyguladıkları reklam stratejileri ile tüketicilerin dikkatini çekmeyi amaçlarlar. Reklamlar filmlerinde firmalar tarafından en sık uygulanan stratejiler; ürünü önceden kullanmış ve memnun kalmış insanların kullamılması, reklam konusu ile ilgili bir uzmanın kullanılması, reklam filminde günlük yaşamdan alınan bir kesitin kullanılması, sosyal medya fenomenlerinin ve televizyon ünlülerin kullanılması sayılabilir. Ülkemizde pek çok firma reklamlarında ünlü kullanılması stratejisini kullanmaktadır. Bu çalışmada Uşak Üniversitesi İletişim Fakültesi öğrencilerinin reklam izleme alışkanlıkları ve reklamlarda ünlü kullanımı stratejisinin nasıl algılandığı araştırılmıştır. Birinci başlıkta pazarlama iletişimi ve reklam kavramına ilişkin literatür, ikinci başlıkta televizyon reklamları ve reklamlarda ünlü kullanılması stratejisine ilişkin literatür ve son başlikta da araştırmanın amacl, yöntemi ve araştırmada elde edilen bulguların analizi yer almıştır.

Anahtar Sözcükler: Ünlüler, Reklam, Televizyon Reklamları, Tüketici Davranışları

\section{Evaluation of Celebrity Usage in Television Advertisements: Research on The Students of Uşak University Communication Faculty}

\begin{abstract}
Companies aim to attract consumers' attention with their advertising strategies. The most common strategies that companies use in advertising film are using people who are already using and satisfied with the product, using an expert in the product, that a cross-section of daily life and finally using social media mikro-celebrities and television celebrities. Many companies in our country use the strategy of using celebrities in their advertisements. In this study, it has been investigated how the perception of Uşak University Faculty of Communication students' ad watching habits and the usage strategy of celebrities in advertising films. The study consists of 3 titles. In the first title, the literature on the concept of marketing communication and advertising, in the second title, the literature on television ads and the strategy of using celebrities in advertisements, and in the last title the aim, method and analysis of the findings obtained in the research are included.
\end{abstract}

Keywords: Celebrities, Advertisement, TV Advertisement, Consumer Behaviour

\section{Giriş}

Günümüzde tüketiciler satın alma davranışında bulunurken birbirine benzer birçok ürün ve marka ile karşılaşmaktadır. Bu durum pazarlamacıların yeni reklam stratejileri aramasına neden olmaktadır. Satış ve farkındalık amaçlı yapılan reklam faaliyetlerinde tanınan kişilerin kullanılmasının örneklerine 18.yy'dan itibaren rastlanmaktadır (Uyar, 2018: 121). 
Kitle iletişim araçları içerisinde önemli yeri olan televizyon, reklam stratejilerinin merkezinde bulunmaktadır. Televizyon reklamları görsel ve işitsel ögelerin aynı anda kullanılması sebebiyle akılda daha kalıcı olmaktadır. Tüm kitle iletişim araçları gibi televizyonunda reklam ortamı olarak kullanılmasında geniş bir kitleye yönelik yapılan bir eylem olması söz konusudur (Odabaşı ve Oyman, 2002: 119).

Tüketiciler kendilerine yakın hissettikleri kişilerin görüşlerine ve davranışlarına daha fazla değer vermektedir. Kendini reklam filminde oynayan ünlü ile özdeşleştiren tüketiciler de reklamda ki ürüne ve markaya daha fazla değer vermektedir. Ünlü kişilerin reklamlarda kullanımı stratejisi hedef kitle üzerinde ilgi uyandırılması ve dikkat çekilmesi amacıyla kullanılmaktadır. Özellikle yeni bir ürün konumlandırılmasında ünlünün çekiciliği ürünün çekiciliğini arttırmaktadır (Ersavaş, 2007: 27).

Reklamlarda ünlülerin kullanılmasıyla ilgili yazılmış tez ve makaleler incelendiğinde bu stratejinin tüketiciler tarafından nasıl algılandığına ve satın alma davranışı üzerinde ne gibi etkilerinin olduğuna yönelik yapılan çalışmalar görülmüştür(Erkal, 2013; İşler, 2014; Uyar, 2018; Solak, 2016). Bu çalışmalara ek olarak televizyon reklamlarında ünlü kullanılmasının reklamın hatırlanması ve marka farkındalığı yaratma üzerindeki etkisine yönelik yapılan çalışmalarda görülmüştür (Çardaklı, 2008; Şıker ve Horzum, 2016).

\section{Pazarlama İletişimi ve Reklam}

Pazarlama, mal ve hizmetlerin mevcut ya da potansiyel tüketicilere sunulma sürecidir. Pazarlama üretim öncesinde başlar ve satış sonrasına kadar da devam eder (Çardakl1, 2008: 1). Günümüzde hedef kitleleri ile doğru iletişim kurmak isteyen firmalar geleneksel pazarlamanın tek yönlü yapısına karşıt olarak hedef kitlenin mesajlarını algılamaya çalışmaktadırlar. Pazarlama iletişimi, firmalar ve hedef kitleleri arasında ki fikir ve anlam alışverişidir (Taşoğlu, 2018: 35).

Pazarlama iletişimi, tüketicilerin ürün veya hizmetin farkına varmaları ve satın alma kararlarının etkilenmesine yönelik çalışmalardır (Taşoğlu, 2018: 39). Pazarlama iletişimi, işletmelerin tüketicilere firmalarını ve ürünlerini tanıtma amacıyla çeşitli pazarlama iletişimi araçlarını kullanarak gerçekleştirdikleri ikna edici bir iletişimdir. $\mathrm{Bu}$ araçlara reklam, halkla ilişkiler, kişisel satış ve doğrudan pazarlama örnek verilebilir (İçli ve Çopur, 2008: 23). Günümüzde hedef kitlelerini olumlu yönde etkilemeyi amaçlayan işletmeler bunu hızlı ve etkili bir yol olan reklam ile gerçekleştirmeye çalışırlar.

Reklam kavramı, Türk Dil Kurumu tarafından reklam "bir şeyi halka tanıtmak, beğendirmek ve böylelikle sürümünü sağlamak için denenen her türlü yol” olarak tanımlanmıştır. Reklamı halkla ilişkilerden ayıran en önemli özelliği reklamın bir ücret karşılığında yapılmasıdır. Reklam, bir pazarlama iletişim yöntemidir (Odabaşı ve Oyman, 2002: 98). İşletmeler reklam ile sunulan mal ve hizmetlerin hedef kitlelerin 
beğeneceği yanlarını anlatarak onlarda yeni ihtiyaçlar uyandırmayı amaçlar(Çardaklı, 2008: 9).

Reklam çeşitli medya aracılığıyla bir ürün veya hizmet hakkında her türlü bilgiyi tüketiciye aktaran ve tüketicileri etkilemeye çalışılan bir araçtır. Reklamın satışı ne kadar etkilediği ve bunda ne kadar başarılı olduğu sıklıkla tartışılan bir konudur.

Reklamcılığın tarihsel gelişimine baktığımızda çok eski zamanlara kadar uzandığını görüyoruz. Reklamın sadece yazı ile ilişkili olmamasından dolayı yazıdan önce de reklama rastlayabiliyoruz. Matbaanın bulunmasıyla başlayan teknolojik gelişmeler gittikçe hızlanarak günümüze kadar gelmiştir. Teknolojide yaşanan bu gelişmeler sayesinde reklam da sürekli olarak gelişmeye devam etmektedir. Dünya tarihinde M.Ö. 3000'li yıllara kadar uzanan reklamın temelleri ülkemizde ancak 1900'lü yıllarda atılmıştır. Özel gazetelerin artması ve okuma yazma oranının yükselmesi reklamcılığında büyük bir gelişme göstermesine yol açmıştır. TRT'nin televizyon yayınına başlaması ve sonrasında reklamları yayınlaması ülkemizde reklamın hızlı bir gelişme göstermesini sağlamıştır. Teknolojik gelişmeler ile paralel olarak ülkemizde reklamcılık giderek etkisini arttırmaktadır (Erkal, 2013: 10-12).

\subsection{Reklamın Amaçları}

Reklamın en temel amacı hedef kitlenin üzerinden farkındalık yaratılarak satışların arttıılmasıdır (Şıker ve Horzum, 2016: 25). Reklamın amaçlarını satış amacı ve iletişim amacı olarak 2'ye ayırabiliriz. Reklamın satış amacı, firmaların ürünün satılmasını sağlamak veya ürüne olan talebi arttırmaktır. İletişim amacı ise tüketicilerin gözünde bilinilirliği arttırılması ve imajı güçlendirmektir (Elden, 2016: 180-187).

Reklamların, tüketicinin ürün ve marka ile ilgili bilgi edinmesini sağlama amaçlı bilgi verici, tüketici algılarının değiştirilmesi amaçlı ikna edici ve tüketicinin ürün ve markayı unutmaması için hatırlatıcı işlevleri vardır (İşler, 2014: 112). Reklam bilgi verir, hatırlatır ve hedef kitleyi ikna etmeye çalışır. Hedef kitleyi ikna etmesi reklamın başarılı olduğunu gösterir.

Reklamlar firmalar için oldukça önemli bir pazarlama iletişim yöntemidir. Tüketiciler, reklamlar sayesinde ürün ve hizmetlere karşı olumlu tutumlar geliştirebilirler. Olumlu tutumların artması satın almayı etkiler. Reklamlar aracılığı ile güçlü bir imaj yaratılabilmektedir (Elden, 2016: 143).

Reklamın satın alma davranışı oluşturmada ki başarısı işletmeler için çok önemlidir. Bu amacı uzun süreli yada kısa süreli satışları arttırma olarak sayabiliriz.

\subsection{Reklam Mecrası Olarak Kitle İletişim Araçları}

İletişim teknolojilerinde yaşanılan gelişmeler hem geleneksel kitle iletişim araçlarının sayıların artmasını hem de internet ile beraber hayatımıza yeni ortamların girmesini sağlamıştır. Kitle iletişim araçlarını reklam amaçı kullanacak firmaların öncelikle bir strateji oluşturması gerekmektedir. Reklam amaçlı kullanılacak kitle iletişim aracı bu stratejiye uygun olarak seçilecektir. Her kitle iletişim aracının hedef kitleye ulaşma, mesaj şekli ve hedef kitleyi etkileme durumları farklılık 
göstermektedir. Reklam amaçlı kullanılacak araçlarını radyo, televizyon, gazete, dergi, posta, transit reklam ortamları ve internet olarak sayabiliriz (Taşoğlu, 2018: 97-100).

\section{Televizyon Reklamları ve Reklamlarda Ünlü Kullanılması}

\subsection{Televizyon Reklamları}

Televizyon, ses ve görüntülerin elektromanyetik dalgalar ile uzaklara iletilmesiyle çalışan bir araçtır. Televizyonun kitle iletişim araçları içerisinde ayrı bir yeri bulunmaktadır. Hem kulağa hem de göze hitap etmesi sebebiyle kitleler üzerinde etkili olmuştur (Elden, 2016: 223).

Televizyon reklamlarının ülkemizde en büyük gelişme gösterdiği dönem TRT'nin reklam kabul etmeye başladığı dönemdir.1980'li yıllarda televizyon yayınlarının ve izlenme oranlarının artması televizyon reklamcılığının gelişmesinde büyük önem taşımaktadır (Erkal, 2013: 11).

Kitle iletişim araçlarının kullanımı günümüzde oldukça yaygındır. Kitle iletişim araçları içerisinde televizyon halen popüler olarak kullanılan bir araçtır. Firmalar, kitle iletişim araçlarının büyük kitlelere ulaşmadaki gücünden yararlanarak, ürün ve markalarının tüketicinin zihinlerinde ki algılarını ve satın alma davranışlarını etkilemeye çalışırlar (İşler, 2014:114).

Ses ve görüntüyü aynı anda iletebilen televizyon, 1940'l1 yıllardan itibaren bir reklam aracı olarak kullanılmaktadır. Günümüzde kitleleri etkileme de ki gücü sebebiyle yoğun bir şekilde kullanılmaktadır (Elden, 2016: 225).

\subsubsection{Televizyon Reklam Türleri}

Televizyon reklamlarında hedef kitleyi etkilemek amacıyla birçok farklı reklam türü ve tekniği kullanılmaktadır. Televizyon reklamlarında kullanılan reklam türlerini hareket unsuru olmayan sesin kullanıldığ 1 hareketsiz reklamlar, ses ile birlikte görüntülerin kullanıldığı hareketli reklamlar, program başlarında ve sonlarında bulunan özel tanıtıcı reklamlar, görüntülerin üstüne koyulan bant reklamları, bilgi verici içerikler içerisine koyulan advertorial reklamlar, dizi ve programlar içerisine reklam olduğu tam olarak belli olmayacak şekilde kullanılan ürün yerleştirme reklamları olarak sayabiliriz (Elden, 2016: 226-228).

İzleyicilerin zapping yapmasını engelleme amacıyla yayın arası reklamlar yerine yayın sırasında gözüken reklamlar kullanılmaktadır. İzleyiciler bu reklamları yayın aralarında çıkan reklamlara göre daha fazla izlenmektedir.

\subsubsection{Televizyon Reklamlarının Avantajları ve Dezavantajları}

Televizyonun kitle iletişim araçları içinde birçok üstü yönü bulunmaktadır. Görsel ve işitsel ögelerin aynı anda kullanılabilmesinden dolayı reklam için en uygun araçtır. Televizyon reklamları görsel ve işitsel ögelerin aynı anda kullanılması sebebiyle akılda daha kalıcı olmaktadır. Tüm kitle iletişim araçları gibi televizyonunda reklam ortamı olarak kullanılmasında geniş bir kitleye yönelik yapılan bir eylem olması söz konusudur. Bununla birlikte tekrar olanağının bulunması ve reklamı 
yapılan ürün ve markanın prestijli gözükmesini sağlaması önemli avantajlardır (Odabaşı ve Oyman, 2002: 119).

Televizyon reklamlarının reklam verenlere reklamın kullanılacağı kanalı ve saati seçme şansı sunması ve bu yönüyle farklı saatlerde farklı hedef kitlelere ulaşılması söz konusudur. Gündüz kuşağı programlarının izleyicilerine yönelik olarak yapılacak bir reklam kampanyasının gündüz saatlerinde yayınlanması ve spor ürünlerine yönelik bir reklam kampanyasının bir spor kanalında yayınlanması ile hedef kitle rahatlikla seçilebilmektedir (Elden, 2016: 229).

En büyük dezavantajı ise yüksek maliyetli olması ve mesajların geçici olmasıdır (Odabaşı ve Oyman, 2002: 119). Televizyon reklamları için hazırlanan reklam filmlerinin maliyeti, reklam filminde oynayacak oyuncuların maliyetleri ve ek olarak bu reklam filmlerini yayınlama maliyeti televizyonun ciddi bütçeler isteyen bir reklam ortamı olmasını sağlamaktadır. İzleyicilerin izledikleri program, dizi veya film reklam arasına girdiğinde başka işlerle uğraşması reklamın hedef kitleye ulaşamamasını sağlamaktadır(Elden, 2016: 230).

\section{2. Ünlü Kavramı ve Televizyon Reklamlarında Ünlü Kişilerin Kullanılması}

Ünlü kavramı Türk Dil Kurumu Sözlüğ̈̈'nde “tanınmış, şöhretli, meşhur, şanlı, namlı" şeklinde tanımlanmaktadır(http://sozluk.gov.tr/). Tüketiciler günümüzde bir ürün veya hizmeti satın alırken birçok benzer ürün veya hizmetle karşılaşmaktadır. Tüketicilerin seçimlerinde ürün veya hizmetin sağladığ 1 nesnel faydanın yanında ürünün sembolik yönü de etkili olmaktadır (Çardaklı, 2008: 54). Tüketiciler ürün ve hizmetlerin taşıdıkları anlamlara da önem vermektedirler.

Uzun yıllardır reklamlarda ünlülerin kullanılması yaygın kullanılan bir stratejidir. $\mathrm{Bu}$ strateji sayesinde ünlünün toplumdaki saygınlığ yararlanılmaktadır. Pazarlama çalışmalarının başarıya ulaşmasında ünlü kişilerin kullanılması önemli yer tutmaktadır. Firmalar reklamlarında kullanılacak ünlünün belirli bir kitlesinin olması ve güvenilir bir imajının olmasını isterler. Reklamda ürünü kullanan ünlü ile duygusal bağ kuran kitleleri reklama ve ürüne daha çok güvenir ve inanırlar (Şıker ve Horzum, 2016: 59). Ünlü kişilerin reklamlarda kullanılması tüketicilerin ürünü daha kolay algılamasını ve daha kolay hatırlamasını sağlamaktadır.

Reklamlarda ünlü kişiler kullanılırken, ünlü ile ürün ve markanın birbirine uygun olması, ünlünün tanınırlığının yüksek olması, ünlünün inanılırlığının yüksek olması ve toplumda ki yeri pazarlama stratejisi için çok önemlidir (Erkal, 2013: 29-32).

Türkiye'de televizyon reklamlarının neredeyse tamamında ünlü kişileri görmekteyiz. Rekabet içerisinde ki firmalar reklam filmlerinde ünlü kullanarak var olmaya çalışmaktadır. Reklamda yer alan kişinin hedef kitle tarafından tanınması ilgiyi arttırmaktadır (Uzunkaya, 2019: 23).

Televizyon reklamlarında ünlüler televizyonun sağladığı esneklikten dolayı hem görüntüleriyle ve sesleriyle hem de sadece sesleriyle yer alabilirler. Bu ünlüleri hedef kitle görüntüleri olmasa bile sadece sesleriyle tanıyabilir (Çardaklı, 2008: 58). 


\subsubsection{Televizyon Reklamlarında Ünlü Kullanılmasının Tüketiciler Üzerine Etkileri}

Tüketiciler için satın alma kararlarında rasyonel faydanın yanında ürünün taşıdığı anlam da etkili olmaktadır. Tüketiciler tüketimleriyle ayrı bir kimlik kazanmaktadırlar. Ünlüler yaşadıkları toplumda idol olarak görülen kişilerdir. Tüketiciler idol olarak seçtikleri ünlü ile benzer satın alma davranışında bulunmaya çalışırlar. Tüketici ünlü ile kendini özdeşleştirdiğinde, reklamda ünlünün kullandığı ürünü satın almaya yönelir. Tüketici dikkatinin ürüne çekilmesi, reklamda oynayan ünlünün çekiciliği ile ilişkilidir. Ünlü kişilerin reklam filmlerinde oynaması, tüketicilerin reklamları daha kolay hatırlamasına yol açmaktadır. İkna, satışların arttırılmasında kullanılan önemli bir stratejidir. Reklamlarda oynayan ünlünün ikna gücüne bağlı olarak reklamında tüketiciler üzerinde ki etkisi artmaktadır. Tüm bu etkileri sebebiyle ünlü kullanımı yaygın kullanılan bir stratejidir (Erkal, 2013: 33-36).

Ünlü kişinin hedef kitle tarafından rol model kabul edilmesi reklamın amaçlarının gerçekleşmesinde önemlidir. Bu kişiler kendilerini rol model alan hedef kitlelerinin satın alma kararları üzerinde doğrudan etkilidir (Uyar, 2018: 122).

\subsubsection{Televizyon Reklamlarında Ünlü Kullanımının Avantajları ve Dezavantajlan}

Reklamlarda ünlü kullanılmasının birçok avantajının bulunmasının yanında birtakım dezavantajları da bulunmaktadır. Reklamlarda ünlü kullanılmasının en büyük avantajı hedef kitle üzerinde ilgi uyandırması ve dikkat çekmesidir. Özellikle yeni bir ürünün konumlandırılmasında ünlü birinin seçilmesiyle ürün daha fazla çekicilik kazanmaktadır (Ersavaş, 2007: 27).

Reklamlarda ünlülerin kullanılması, günümüz pazarlama dünyasında ve medya ortamında işletmelerin benzer işletmelerden sıyrılmasını ve iletişim gücünün artmasını sağlar. Firma imajı onarma ve oluşturmada da reklamlarda ünlü kullanılması kullanılan bir yoldur. Yabancı ülke pazarlarına girişte de o ülkede tanınan ve sevilen bir ünlü ile çalışılması büyük katkılar sağlamaktadır.

Reklamlarda ünlü kullanılmasının avantajlarının yanında birtakım dezavantajları da bulunmaktadır. Reklamlarda eğer dikkat edilmezse ünlü ürünü arka planda bırakıp kendi ön plana çıabilir. Bu durumda reklam ürün ve marka yerine ünlünün reklamını yapmış olur (Uyar, 2018: 123).

Reklam kampanyasında ünlü bir kişinin kullanılması büyük bir bütçe gerektirmektedir. Kampanyada kullanılan ünlünün imajının sarsılması, birçok kampanyada yer alması sebebiyle toplum gözünde ki inanılırlı̆̆ını kaybetmesi söz konusu olabilir. Reklam kampanyasında kullanılan ünlünün ürün ile uyumsuz olması durumunda da kampanyanın etkisi azalacaktır (Ersavaş, 2007: 28). Reklamlarda ünlü kullanılmasının potansiyel bir riski de ünlünün herhangi bir suça veya olaya karışması durumunda markanın da halkın gözünde ki imajı sarsılabilir (Çardaklı, 2008: 61). 


\section{ARAŞTIRMANIN AMACI VE YÖNTEMI}

$\mathrm{Bu}$ çalışmanın amacl, reklamlarda ünlü kullanımının tüketici üzerindeki etkisinin belirlenmesidir. Reklamlarda ünlü kullanımı firmaların büyük bütçeler ayırdığı bir stratejidir. Bu çalışmada ünlü kullanımının tüketicileri etkileme de başarılı olup olmadığı anlaşılmaya çalışılmıştır. Tüketicilerin ünlü kullanımına bakışları demografik özelliklerine göre analiz edilmiştir.

Araştırma amacına uygun olarak, araştırma ile ilgili oluşturulan hipotezleri şu şekilde siralamak mümkündür.

- H1: Reklamda Ünlü Kullanımına İlişkin Görüşler katılımcıların cinsiyetlerine göre farklılık göstermektedir.

- H2: Reklamda Ünlü Kullanımına İlişkin Görüşler katılımcıların yaşlarına göre farklılık göstermektedir.

- H3: Reklamda Ünlü Kullanımına İlişkin Görüşler katılımcıların gelirlerine göre farklılık göstermektedir.

- H4: Reklamda Ünlü Kullanımına İlişkin Görüşler katılımcıların eğitim gördükleri bölümlere göre farklılık göstermektedir.

Araştırmada birincil veri toplama yöntemlerinden biri olan anket yöntemi kullanılmıştır. Anket formu oluşturulurken literatürde bulunan çalışmalar incelenmiş ve Erkal'ın (2013) çalışmasında kullandığı anket formu üzerinde araştırma amacına uygun olacak şekilde bazı değişiklikler yapılarak yararlanılmıştır.

Anket verilerinin değerlendirilmesi aşamasında SPSS programı kullanılmıştır. Toplanan veriler frekans, yüzde dağılımı, ortalama ve standart sapma değerleri hesaplanarak analiz edilmiştir. Çalışmanın geçerliliği ve güvenilirliği için Cronbach's Alpha testi ve Faktör Analizi yapılmıştır. Elde edilen verilerin demografik özellikler ile karşılaştırılmasında t-Testi ve Varyans analizi kullanılmıştır.

\subsection{Anket Formunun Hazırlanması ve Uygulanması}

Anket formu hazırlanırken bazı sorular olduğu gibi alınmış bazı sorular ise araştırma amacına ve oluşturulan hipotezlere uygun olacak şekilde düzenlenmiştir. Hazırlanan anket formu üzerinde pilot çalışma sonrası bazı düzenlemeler yapılmıştır. Anket formunda katılımcıların demografik özelliklerini belirleme amacıyla 5 adet demografik soru, 8 adet katılımcıların televizyon ve reklam izleme alışkanlıkları ile reklamlar ile ilgili tutumlarının saptanmasına yönelik soru ve 8 adet reklamda ünlü kullanımı ve satın alma davranışının ölçülmesine yönelik likert soru olmak üzere toplam 21 soru yer almiştır.

Anket formu Uşak Üniversitesi İletişim Fakültesinde bulunan her bölüm için 100 adet olacak şekilde toplam 400 adet uygulanmıştır.

\subsection{Araştırma Kapsamı}

Araştırma evrenini Uşak Üniversitesi İletişim Fakültesi'nde eğitim gören öğrenciler oluşturmaktadır. Uşak Üniversitesi İletişim Fakültesi'nde Halkla İlişkiler ve Reklamcılık, Radyo Televizyon ve Sinema, Gazetecilik ve Yeni Medya olmak üzere 
toplam 4 bölüm bulunmaktadır. Araştırmanın örneklemini ise, Uşak Üniversitesi İletişim Fakültesi'nde okuyan 400 öğrenci oluşturmaktadır.

Araştırma evrenini Uşak Üniversitesi İletişim Fakültesinde okuyan öğrencilerin oluşturması araştırmanın temel sınırlılığıdır.

\subsection{Araştırmanın Geçerliliği ve Güvenilirliği}

Örneklem büyüklüğünün faktör analizine uygun olduğunun belirlenmesi amaciyla KMO testi ve verilerin normal dağılıma uygun olduğunu belirlemek amacıyla Barlett küresellik testi yapılmıştır. Elde edilen sonuçlara göre KMO değeri 0,840 çıkmıştır. KMO değerinin 0,80 üzerinde çıkması örneklemin faktör analizi açısından yeterliliğinin çok iyi olduğu söylenebilir(İslamoğlu ve Alnıaçık, 2016: 423). Barlett test sonuçlarının $(, 000)$ ise anlamlı olduğu görülmüştür. Faktör analizi sonucunda 8 ifade tek faktörde toplanmıştır. Analiz sonucunda ölçeğin öz değeri 3,18 olarak hesaplanmıştır. Tek faktörlü ölçeklerde varyansın \%30dan büyük olması yeterli görülmektedir. Yapılan çalışmada ölçeğin açıklanan varyansı \%39,769'dur.

Tablo 1. Reklamlarda Ünlü Kullanımına İlişkin İfadelere Yönelik Faktör Analizi

\begin{tabular}{|c|c|}
\hline Ífadeler & Faktör Yükleri \\
\hline $\begin{array}{l}\text { Ünlülerin reklamlarda kullanılması, dikkat çekiciliği } \\
\text { arttırmaktadır. }\end{array}$ & ,772 \\
\hline $\begin{array}{l}\text { Ünlülerin reklamlarda rol almaları, tüketicilerin o ürüne ilgi } \\
\text { duymalarını sağlamaktadır. }\end{array}$ & ,758 \\
\hline $\begin{array}{l}\text { Ünlülerin yer aldığı reklamlar diğer reklamlara oranla daha } \\
\text { fazla izlenmektedir. }\end{array}$ & ,666 \\
\hline $\begin{array}{l}\text { Ünlülerin reklamlarda kullanımı, ürünün akılda kalıcılığını } \\
\text { sağlamaktadır. }\end{array}$ & ,661 \\
\hline $\begin{array}{l}\text { Reklamlarda ünlü kullanılması, ürünün tanıtımı açısından } \\
\text { reklamın inandırıcılığını arttırmaktadır. }\end{array}$ &, 574 \\
\hline $\begin{array}{l}\text { Ünlülerin imajını taklit eden tüketiciler, reklamda kullanılan } \\
\text { ünlü ile kendini özdeşleştirmekte ve tüketime yönelmektedir. }\end{array}$ &, 540 \\
\hline $\begin{array}{l}\text { Tüketicilerin bir ürünü satın almaya istek duymasını sağlamak } \\
\text { amacıyla ünlü kişiler kullanılmaktadır. }\end{array}$ &, 529 \\
\hline $\begin{array}{l}\text { Reklamlarda kullanılan ünlünün birden fazla firmanın } \\
\text { reklamında gözükmesi, reklamı yapılan markaya ait ürünü } \\
\text { satın alma kararında etkili olmaktadır. }\end{array}$ & 479 \\
\hline $\mathbf{N} \quad$ Min & Ort \\
\hline Reklamlarda Ünlü Kullanımı Ölçeği & 4,08 \\
\hline
\end{tabular}

Araştırmada ölçüm aracının güvenilirliğinin tespiti için yaygın kullanılan yöntemlerden birisi Cronbach $\alpha$ katsayısıdır. Cronbach $\alpha$ katsayısı 0 ile 1 arasında bir değer almaktadır. Katsayı 1'e yaklaştıkça ölçeğin tutarlılığı artmaktadır(İslamoğlu ve Alnıaçık, 2016: 292). Bu araştırmada güvenilirlik analizi sonucunda Cronbach $\alpha$ katsayısı 0,771 çıkmıştır. 


\section{Araştırmanın Bulguları}

$\mathrm{Bu}$ bölümde Uşak Üniversitesi İletişim fakültesinde okuyan öğrencilerin ankette bulunan sorulara verdikleri cevaplar analiz edilmiş ve tablo halinde özetlenmiştir.

\subsection{Demografik Bulgular}

Katılımcıların demografik özellikleri, cinsiyet, yaş, eğitim gördükleri bölüm, sınıf ve gelir kriterlerine göre değerlendirilmiştir.

Tablo 2. Katılımcıların Demografik Özellikleri

\begin{tabular}{|c|c|c|c|c|c|}
\hline \multicolumn{6}{|c|}{ Demografik ve Ekonomik Özellikler } \\
\hline Cinsiyet & Frekans(f) & Yüzde(\%) & Yaş & Frekans(f) & Yüzde(\%) \\
\hline Kadın & 224 & 56 & 18 ve alt & 16 & 4 \\
\hline Erkek & 176 & 44 & 19 & 77 & 19 \\
\hline Bölüm & Frekans(f) & Yüzde(\%) & 20 & 108 & 27 \\
\hline $\begin{array}{l}\text { Halkla İlişkiler ve } \\
\text { Reklamcılık }\end{array}$ & 100 & 25 & 21 & 78 & 19 \\
\hline $\begin{array}{l}\text { Radyo, } \\
\text { Televizyon ve } \\
\text { Sinema }\end{array}$ & 100 & 25 & 22 & 77 & 20 \\
\hline Gazetecilik & 100 & 25 & 23 & 28 & 7 \\
\hline Yeni Medya & 100 & 25 & 24 ve üstü & 16 & 4 \\
\hline Sinif & Frekans(f) & Yüzde(\%) & Gelir & Frekans(f) & Yüzde(\%) \\
\hline 1.sinif & 121 & 30 & $0-400 \mathrm{TL}$ & 49 & 12 \\
\hline 2.sinif & 126 & 32 & $401-800 \mathrm{TL}$ & 188 & 47 \\
\hline 3.sinif & 85 & 21 & $801-1200 \mathrm{TL}$ & 124 & 31 \\
\hline 4.sinif & 68 & 17 & 1201 ve üst & 39 & 10 \\
\hline & & & Toplam & 400 & 100 \\
\hline
\end{tabular}

Katılımcıların, \%56'sı kadın, \%44'ü erkektir. \%4'ü 18 yaş ve altı, \% 19'u 19, $\% 27^{\prime}$ si $20, \% 19^{\prime}$ u $21, \% 20^{\prime}$ si $22, \% 7^{\prime}$ si 23 ve $\% 4^{\prime} \ddot{u} 24$ yaş ve üstü yaş grubunda yer almaktadır. Katılımcıların okudukları bölümde bulundukları sınıflara bakıldığında \%30'u 1.sınıf, \%32'si 2.sınıf, \%21'i 3.sınıf ve \%17'si de 4.sınıf ta eğitim görmektedirler. Katılımcıların gelirlerine bakıldığında \%12'unun 0-400 TL, \%47'sinin 401-800 TL, \%31'inin 801-1200TL ve \%10'unun 1201 TL ve üstü gelire sahip olduklar1 görülmektedir.

\subsection{Katılımcıların Televizyon ve Reklam İzleme Alışkanlıkları}

Katılımcıların televizyon izleme alışkanlıkları ve reklam izleme alışkanlıkları, günlük ortalama televizyon izleme süreleri ve reklam izleme durumlarına göre değerlendirilmiştir. 
Tablo 3. Katılımcıların Günlük Ortalama Televizyon İzleme Süreleri

\begin{tabular}{lcc}
\hline & Frekans & Yüzde \\
\hline $0-60 \mathrm{dk}$ & 268 & 67 \\
$61-120 \mathrm{dk}$ & 95 & 23,8 \\
$121-180 \mathrm{dk}$ & 29 & 7,2 \\
$181-240 \mathrm{dk}$ & 8 & 2 \\
\hline Toplam & $\mathbf{4 0 0}$ & $\mathbf{1 0 0}$ \\
\hline
\end{tabular}

Ankete katılan katılımciların günlük ortalama televizyon izleme sürelerine bakıldığında \%67'sinin 0-60 dk, \%23,8'inin 61-120 dk, \%7,2'sinin 121-180 dk ve $\% 2$ 'sininde 181-240 dk ortalama televizyon izledikleri görülmüştür. Araştırmanın geçerliliğinin ve güvenilirliğinin sağlanması için örneklemde ki katılımcıların araştırma konusu ile ilgili olması önemlidir.

Tablo 4. Katılımcıların Reklam İzleme Alışkanlıkları

\begin{tabular}{lcc}
\hline & Frekans & Yüzde \\
\hline İlgiyle izlerim & 26 & 6,5 \\
Genellikle izlerim & 47 & 11,8 \\
İlgimi çekerse izlerim & 179 & 44,7 \\
TV dışında işlerle uğraşırım & 74 & 18,5 \\
Kanalı değiştiririm & 74 & 18,5 \\
\hline Toplam & $\mathbf{4 0 0}$ & $\mathbf{1 0 0}$ \\
\hline
\end{tabular}

Katılımcılara televizyon izlerken reklamlar başladığında ne yaparsınız? sorusu sorulmuştur. Bu soruya verilen cevaplara bakıldığında \%44,7'si ilgimi çekerse izlerim, $\% 18,5$ 'i TV dışında işlerle uğraşırım, \%18,5'i kanalı değiştiririm, \%11,8'i genellikle izlerim ve \%6,5'i ilgiyle izlerim yanıtını vermiştir. Katılımcıların büyük çoğunluğu reklam ilgisini çektiği taktirde reklamları izlemektedir.

\subsection{Katılımcıların Reklamlardan Etkilenebilirliği ve Ünlülere Bakış Açıları}

Katılımcıların reklamlardan etkilenebilirliği ve ünlülere bakış açıları, reklamlarda etkilendikleri özellikler, reklam mesaj sunucularının etkililiği, hatırladıkları reklamdaki özellik ve bu özellik karşısında satın alma davranışı, televizyon reklamlarında ünlü kullanılmasına yönelik tepkileri ve etkilerine göre değerlendirilmiştir.

Tablo 5. Katılımcıların Reklamlarda Etkilendikleri Özellikler

\begin{tabular}{lcc}
\hline & Frekans & Yüzde \\
\hline Ünlü kullanılmasına & 22 & 5,5 \\
Yayınlanma sıklı̆̆ına & 30 & 7,5 \\
Reklamın verdiği mesaja & 199 & 49,8 \\
Reklamın müziğine & 108 & 27,0 \\
Reklamın sloganına & 39 & 9,8 \\
Kayıp & 2 & 0,5 \\
\hline Toplam & $\mathbf{4 0 0}$ & $\mathbf{1 0 0}$ \\
\hline
\end{tabular}


Katılımcılara reklamlarda etkilendikleri özellikler sorulduğunda katılımcıların $\% 49,8^{\prime}$ i reklamın verdiği mesaja, \%27'si reklamın müziğine, \%9,8'i reklamın sloganına, \%7,5'i yayınlanma sıklığına ve \%5,5'i de ünlü kullanılmasına yanıtını vermiştir. Katılımcıların reklamlarda etkilendiklerine özelliklere bakıldığında reklamın verdiği mesaj en etkili özellik olmuştur. Reklamda ünlü kullanılmasına cevabının çok az verildiği görülmektedir.

Tablo 6. Katılımcıların Reklam Mesaj Sunucularının Etkililiği

\begin{tabular}{lcc}
\hline & Frekans & Yüzde \\
\hline Ünlü tanınmış kişi & 100 & 25 \\
Halktan ürünü kullanmış kişi & 83 & 20,8 \\
Konunun uzmanı bir kişi & 167 & 41,7 \\
Diş ses & 48 & 12 \\
Kayıp & 2 & 0,5 \\
\hline Toplam & $\mathbf{4 0 0}$ & $\mathbf{1 0 0}$ \\
\hline
\end{tabular}

Katılımcılara sorulan reklam mesajını kimin vermesinin daha etkili olacağı sorusuna verilen cevapların dağılımına bakacak olursak katılımcıların \%41,7'si konunun uzmanı bir kişi, \%25'i ünlü tanınmış bir kişi, \%20,8'i halktan ürünü kullanmış bir kişi ve \%12'side dış ses yanıtını vermiştir. Reklam sunucularının kimin olduğu reklamın tüketicileri etkilemesi açısından önemlidir.

Tablo 7. Katılımcıların Son Hatırladıkları Reklamda Etkili Olan Özellik

\begin{tabular}{lcc}
\hline & Frekans & Yüzde \\
\hline Müzik & 110 & 27,5 \\
Slogan & 94 & 23,5 \\
Reklamda kullanılan ünlü & 65 & 16,3 \\
Mesaj & 82 & 20,5 \\
Yayınlanma sıklığı & 49 & 12,3 \\
\hline Toplam & $\mathbf{4 0 0}$ & $\mathbf{1 0 0}$ \\
\hline
\end{tabular}

Katılımcılara son hatırladıkları reklamda etkili olan özelliğin ne olduğu sorusu sorulmuştur. Bu soruya verilen yanitlara bakacak olursak katılımciların \%27,5'i müzik, \%23,5'i slogan, \%20,5'i mesaj, \%16,3'ü reklamda kullanılan ünlü ve \%12,3'ü de yayınlanma sıklığı yanıtını vermiştir. Reklamda kullanılan ünlü diğer iki özelliğin arkasında kalmıştır.

Tablo 8. Katılımcıların Son Hatırladıkları Reklam Karşısında Gösterdikleri Satın Alma Davranış1

\begin{tabular}{lcc}
\hline & Frekans & Yüzde \\
\hline Satın aldım & 46 & 11,5 \\
Satın almayı düşünmedim & 241 & 60,2 \\
Satın almayı düşünüyorum & 113 & 28,3 \\
\hline Toplam & $\mathbf{4 0 0}$ & $\mathbf{1 0 0}$ \\
\hline
\end{tabular}

Katılımcılara son hatırladıkları reklam karşısında gösterdikleri satın alma davranışı sorulduğunda katılımcıların \%60,2'si satın almayı düşünmedim, \%28,3'ü 
satın almayı düşünüyorum ve \%11,5'i satın aldım yanıtını vermiştir. Katılımcılar son hatırladıkları reklam karşısında büyük oranda satın almayı düşünmemiştir. Katılımcıların zihinlerinde reklam hatırlanabilir olsa da reklamın satın almaya doğrudan yönlendirdiğini söyleyemeyiz.

Tablo 9. Katılımcıların Televizyon Reklamlarında Ünlü Kullanılmasına Yönelik Tepkileri

\begin{tabular}{lcc}
\hline & Frekans & Yüzde \\
\hline Reklamı daha kolay hatırlamama yardımcı olur & 164 & 41 \\
Oynayan kişiye bağlı olarak reklam daha çok ilgimi çeker & 81 & 20,3 \\
Reklamı yapılan ürüne güvenmemi sağlar & 41 & 10,3 \\
Reklam inandırıcılık kazanır & 24 & 6 \\
Bu tür reklamlar beni etkilemez & 90 & 22,4 \\
\hline Toplam & $\mathbf{4 0 0}$ & $\mathbf{1 0 0}$ \\
\hline
\end{tabular}

Reklamlarda ünlü kullanılmasına ilişkin katılımcılara sorulan soruya katılımcıların \%41'i reklamı daha kolay hatırlamama yardımcı olur, \%22,4'ü bu tür reklamlar beni etkilemez, \%20,3'ü oynayan kişiye olan tutumuma bağlı olarak reklam daha çok ilgimi çeker, $\% 10,3$ 'ü reklamı yapılan ürüne güvenmemi sağlar ve $\% 6$ 'sı da reklam inandırıcılık kazanır yanıtını vermiştir. Reklamlarda ünlü kullanılmasının amaçlarından biri olan reklamın ve ürünün daha kolay hatırlanması büyük oranda cevap olarak verilmiştir.

Tablo 10. Reklamlarda Ünlü Kullanılmasının Etkileri

\begin{tabular}{lcc}
\hline & Frekans & Yüzde \\
\hline Ürüne olan algımı değiştirir & 101 & 25,3 \\
Tutum ve inançlarımı etkiler & 61 & 15,2 \\
Ürünü daha kolay tanımamı sağlar & 160 & 40 \\
Kişiliğimi etkiler & 30 & 7,5 \\
Ürünü satın almaya yönlendirir & 46 & 11,5 \\
Kayıp & 2 & 0,5 \\
\hline Toplam & $\mathbf{4 0 0}$ & $\mathbf{1 0 0}$ \\
\hline
\end{tabular}

Reklamda ünlü kullanılmasının satın alma davranışına yönlendirip yönlendirmediğini anlamak amacıyla sorulan soruya katılımcıların $\% 40$ ' 1 ürünü daha kolay tanımamı sağlar, \%25,3'ü ürüne olan algımı değiştirir, \% 15,2'si tutum ve inançlarımı etkiler, \%11,5'i ürünü satın almaya yönlendirir ve \%7,5'i de kişiliğimi etkiler yanıtını vermiştir. Tablo 10'a baktığımızda reklamlarda ünlü kullanımı ürünü satın almaya yönlendirir cevabı düşük düzeyde katılım bulmuştur. 
Tablo 11. Reklamda Ünlü Kullanımına İlişkin Görüşler

\begin{tabular}{llccc}
\hline İfadeler & N & Ortalama & $\begin{array}{c}\text { Standart } \\
\text { Sapma }\end{array}$ \\
\hline $\begin{array}{l}\text { Ünlülerin reklamlarda kullanılması, dikkat çekiciliği } \\
\text { artırmaktadır. }\end{array}$ & 400 & 4,32 & 0,866 \\
\hline $\begin{array}{l}\text { Ünlülerin reklamlarda rol almaları, tüketicilerin o } \\
\text { ürüne ilgi duymalarını sağlamaktadır. }\end{array}$ & 400 & 4,09 & 0,875 \\
\hline $\begin{array}{l}\text { Ünlülerin yer aldığ1 reklamlar diğer reklamlara oranla } \\
\text { daha fazla izlenmektedir. }\end{array}$ & 399 & 4,12 & 0,856 \\
\hline $\begin{array}{l}\text { Ünlülerin reklamlarda kullanımı, ürünün akılda } \\
\text { kalıcılığını sağlamaktadır. }\end{array}$ & 398 & 4,28 & 0,803 \\
\hline $\begin{array}{l}\text { Reklamlarda ünlü kullanılması, ürünün tanıtımı } \\
\text { açısından reklamın inandırıcılığını artırmaktadır. }\end{array}$ & 398 & 3,55 & 1,111 \\
\hline $\begin{array}{l}\text { Ünlülerin imajını taklit eden tüketiciler, reklamda } \\
\text { kullanılan ünlü ile kendini özdeşleştirmekte ve }\end{array}$ & 399 & 4,12 & 0,872 \\
tüketime yönelmektedir.
\end{tabular}

Tablo incelendiğinde katılımcıların en fazla "Ünlülerin reklamlarda kullanılması, dikkat çekiciliği arttırmaktadır." ifadesini desteklediği görülmektedir. Bu ifadenin ortalaması 4.32 'dir. Bu ortalamaya bakarak katılımcıların birçoğunun reklamlarda ünlülerin kullanılmasının dikkat çekiciliği arttırdığı görüşüne sahip olduğu anlaşılmaktadır. Katılımcılar tarafından en az desteklenen görüş "Reklamlarda ünlü kullanılması ürünün tanıtımı açısından reklamın inandırıcılığını arttırmaktadır" ifadesi olmuştur. Bu ifadeye katılım düzeyi diğer ifadelere göre düşük olmasına rağmen 3.55 ortalamaya sahiptir. Tablo 11'e bakıldığında reklamlarda ünlü kullanılmasına ilişkin görüşlere katılım ortalaması yüksektir.

\subsection{Reklamlarda Ünlü Kullanımının Demografik Özelliklere Göre Karşılaştırılması}

Katılımcıların demografik özellikleri ile ünlü kullanımına ilişkin görüşleri karşılaştırılmıştır.

Tablo 12. Reklamlarda Ünlü Kullanımına İlişkin Görüşleri Cinsiyete Göre Karşılaştıran T-Test

\begin{tabular}{lcccc}
\hline Cinsiyet & $\mathbf{N}$ & Ortalama & $\begin{array}{c}\text { Standart } \\
\text { Sapma }\end{array}$ & $\begin{array}{c}\text { Anlamlılık } \\
\text { Düzeyi (Sig.) }\end{array}$ \\
\hline Kadın & 224 & 4,11 &, 513 &, 231 \\
Erkek & 176 & 4,04 &, 607 &, 231 \\
\hline
\end{tabular}

Tablo 12'de reklamlarda ünlü kullanımına ilişkin görüşlerin cinsiyete göre karşılaştıran T-Test gösterilmektedir. Tabloya göre reklamlarda ünlü kullanımına ilişkin görüşlerin cinsiyete göre farklılaşmadığı görülmektedir. "H1: Reklamda ünlü 
kullanımına ilişkin görüşler katılımcıların cinsiyetlerine göre farklılık göstermektedir" hipotezi reddedilmiştir.

Tablo 13. Reklamlarda Ünlü Kullanımına İlişkin Görüşleri Yaşa Göre Karşılaştıran Varyans Analizi

\begin{tabular}{|c|c|c|c|c|c|}
\hline Yaş & $\mathbf{N}$ & Ortalama & $\begin{array}{c}\text { Standart } \\
\text { Sapma }\end{array}$ & $\begin{array}{c}\text { Standart } \\
\text { Hata }\end{array}$ & $\begin{array}{c}\text { Anlamlılık } \\
\text { Düzeyi (Sig.) }\end{array}$ \\
\hline 18 ve alt & 16 & 3,92 & 741 & 185 & \multirow{8}{*}{,094 } \\
\hline 19 & 77 & 3,97 & 612 & ,069 & \\
\hline 20 & 108 & 4,09 & 616 & ,059 & \\
\hline 21 & 78 & 4,08 & 462 & ,052 & \\
\hline 22 & 77 & 4,11 &, 519 & ,059 & \\
\hline 23 & 28 & 4,20 & ,424 & 080 & \\
\hline 24 ve üzeri & 16 & 4,39 & 303 & 075 & \\
\hline Toplam & 400 & 4,08 & ,557 & ,027 & \\
\hline
\end{tabular}

Tablo 13'de reklamlarda ünlü kullanımına ilişkin görüşleri yaşa göre karşılaştıran Varyans analizi gösterilmektedir. Tabloya göre reklamlarda ünlü kullanımına ilişkin görüşlerin yaşa göre farklılaşmadığ görülmektedir. “H2: Reklamda Ünlü Kullanımına İlişkin Görüşler katılımcıların yaşlarına göre farklılık göstermektedir." hipotezi reddedilmiştir.

Tablo 14. Reklamlarda Ünlü Kullanımına İlişkin Görüşleri Gelire Göre Karşılaştıran Varyans Analizi

\begin{tabular}{lccccc}
\hline Gelir & N & Ortalama & $\begin{array}{c}\text { Standart } \\
\text { Sapma }\end{array}$ & $\begin{array}{c}\text { Standart } \\
\text { Hata }\end{array}$ & $\begin{array}{c}\text { Anlamlılık } \\
\text { Düzeyi (Sig.) }\end{array}$ \\
\hline $0-400 \mathrm{TL}$ & 49 & 4,07 &, 705 &, 100 & \\
$401-800 \mathrm{TL}$ & 188 & 4,08 &, 511 &, 037 & \\
801-1200 TL & 124 & 4,09 &, 565 &, 050 &, 996 \\
1201 TL ve üst & 39 & 4,08 &, 556 &, 089 & \\
\cline { 1 - 4 } Toplam & $\mathbf{4 0 0}$ & $\mathbf{4 , 0 8}$ & $\mathbf{5 5 7}$ & $\mathbf{0 2 7}$ & \\
\hline
\end{tabular}

Tablo 14'de reklamlarda ünlü kullanımına ilişkin görüşleri gelire göre karşılaştıran Varyans analizi gösterilmektedir. Tabloya göre reklamlarda ünlü kullanımına ilişkin görüşlerin gelire göre farklılaşmadığ1 görülmektedir. "H3: Reklamda Ünlü Kullanımına İlişkin Görüşler katılımcıların gelirlerine göre farklılık göstermektedir." hipotezi reddedilmiştir.

Tablo 15. Reklamlarda Ünlü Kullanımına İlişkin Görüşleri Eğitim Görülen Bölüme Göre Karşılaştıran Varyans Analizi

\begin{tabular}{|c|c|c|c|c|c|}
\hline Bölüm & $\mathbf{N}$ & Ortalama & $\begin{array}{c}\text { Standart } \\
\text { Sapma }\end{array}$ & $\begin{array}{c}\text { Standart } \\
\text { Hata }\end{array}$ & $\begin{array}{l}\text { Anlamlılık } \\
\text { Düzeyi(Sig.) }\end{array}$ \\
\hline Halkla İlişkiler ve Reklamcılık & 100 & 3,87 &, 546 & 054 & \\
\hline Radyo, Televizyon ve Sinema & 100 & 4,13 & 619 & ,061 & \\
\hline Gazetecilik & 100 & 4,05 & 602 & ,060 & ,000 \\
\hline Yeni Medya & 100 & 4,28 & ,342 & 034 & \\
\hline Toplam & 400 & 4,08 & ,557 & ,027 & \\
\hline
\end{tabular}


Tablo 15'de reklamlarda ünlü kullanımına ilişkin görüşleri eğitim görülen bölüme göre karşılaştıran Varyans analizi gösterilmektedir. Tabloya göre reklamlarda ünlü kullanımına ilişkin görüşlerin eğitim görülen bölümlere göre farklılaştı̆̆ 1 görülmektedir. “H4: Reklamda Ünlü Kullanımına İlişkin Görüşler katılımcıların eğitim gördükleri bölümlere göre farklılık göstermektedir." hipotezi kabul edilmiştir.

\section{Sonuç}

Reklamlarda ünlü kullanım stratejisi uzun süredir firmalar tarafından kullanılmaktadır. Ünlüler toplumda saygı gören kişilerdir. Bir ürün ya da hizmetin tüketicilere tanıtılmasında ünlülerin kullanılması etkili olmaktadır. Toplumda saygı gören kişiler olduklarından dolayı tüketicilerin ürüne ya da hizmete güvenmesi ve ilgilerinin çekilmesi söz konusudur. Ünlüler reklamlarda hem ses hem de ses ve görüntüleriyle bulunabilirler. Bu çalışma Uşak Üniversitesi'nde yapılmış olup iletişim fakültesinde gerçekleştirilmiştir. Bu çalışma ile Uşak Üniversitesi iletişim fakültesi öğrencilerinin reklamda ünlü kullanımına dair düşünceleri ve tutumları ortaya çıkarılmaya çalışılmıştır.

Tablo 3'e göre katılımcıların çoğunluğu günlük ortalama 0-60 dakika televizyon izlemektedir. Tablo 4'e göre Uşak Üniversitesi İletişim Fakültesi öğrencileri büyük oranda reklamları izlemektedir ve izledikleri reklamlarda da en etkili özellik reklamın verdiği mesajdır. Bu da gösteriyor ki reklamlarda ünlü kullanılması reklamdan etkilenmekte düşük katılım alan bir özelliktir. Tablo 6'ya göre reklam mesajının sunucusu konunun uzmanı bir kişi olmalıdır cevabı $(\% 41,7)$ en fazla alınan cevap olmuştur. Tablo 7 ve 8'e göre katılımcıların son hatırladıkları reklamda bulunan özellik $(\% 27,5)$ müziktir ve bu özellik karşısında katılımcilar $(\% 60,2)$ satın almayı düşünmektedir. Tablo 9 ve 10 'a göre reklamlarda ünlü kullanılması büyük oranda ürünün kolay tanınması ve hatırlanmasında etkilidir. Katılımcılara reklamda ünlü kullanımına ilişkin beşli likert ölçeğine göre sorular sorulmuş ve Tablo 11'e göre "Ünlülerin reklamlarda kullanılması, dikkat çekiciliği arttırmaktadır." görüşü en çok onaylanan görüştür. Reklamlarda ünlü kullanılmasının firmaların amaçladığı, ürünün akılda kalıcılığının sağlanması, ünlülerin imajını taklit eden tüketicileri satın almaya yönlendirmesi, ürüne karşı ilgi duyulmasını sağlaması ifadeleri de yüksek ortalama ile onaylanmıştır. Uşak Üniversitesi İletişim Fakültesi öğrencilerin ünlülerin reklamlarda kullanılmasına ilişkin ifadelerin neredeyse tamamını onaylamıştır.

Çalışmada Uşak Üniversitesi İletişim Fakültesinde okuyan öğrencilerin ünlü kullanılmasına ilişkin görüşleri cinsiyet, yaş, gelir ve eğitim gördükleri bölüm özelliklerine göre araştırılmış sadece eğitim görülen bölüme göre bir farklılık gözlenmiştir. H1, H2 ve H3 hipotezleri reddedilmiş, $\mathrm{H} 4$ hipotezi kabul edilmiştir.

Literatürde ki çalışmalar ile elde edilen sonuçları karşılaştırdığımızda Akdeniz Üniversitesi iletişim fakültesi öğrencilerine yönelik Solak(2016)'ın yaptığı çalışmada katılımcıların hatırladıkları reklam filmindeki ürünü veya hizmeti satın aldığı sonucuna ulaşılmıştır. Aynı soru Uşak Üniversitesi iletişim fakültesi öğrencilerine sorulduğunda ise katılımcıların satın almayı düşünmediği sonucuna ulaşılmıştır. Bu sonuca benzer şekilde Akdeniz Üniversitesi öğrencileri ile Uşak Üniversitesi 
öğrencileri son hatırladıkları reklam özelliği konusunda da birbirlerinden ayrılmaktadır. Demografik özellikler karşılaştırıldığında gelir ortalamalarının birbirinden gözle görülür oranda farklılaştığı görülmektedir. Reklam izleme alışkanlıkları, reklamda etkilenilen özellikler ve reklam mesaj sunucusu yönünden benzer sonuçlara ulaşılmıştır. Literatürde yapılan çalışmalarda reklamlarda ünlü kullanılmasına ilişkin görüşlerin cinsiyet, yaş ve gelire göre farklılaşmadığ görülmektedir(Uyar, 2018: 125). Bu çalışmada da benzer sonuçlara ulaşılmıştır. Katılımcıların cinsiyet, yaş ve gelirleri reklamda ünlü kullanılmasına ilişkin görüşlerde etkili olmamıştır. Ünlü kavramının çok geniş bir kavram olması sebebiyle bu sonuçlar normal kabul edilebilir. İletişim fakültesi öğrencilerinin reklamlarda ünlü kullanımına ilişkin görüşleri aldıkları eğitiminde etkisiyle eğitim görülen bölüme göre farklılaşmaktadır.

Araştırma sonuçlarına dayanarak yapılabilecek öneriler şunlardır: Reklamlarda ünlü kullanım stratejisi reklamın hatırlanmasını kolaylaştırmakta ve ürünün de akılda kalıcılığını sağlamaktadır. Bu strateji sayesinde işletmeler ürün ve hizmetlerine istenen dikkati çekebilmektedirler. Hedef kitle tarafından güvenilen ve sevilen ünlülerle reklam kampanyalarında çalışılması tüketiciler üzerinde istenen etkiyi bırakılabilecektir. Reklamlarda ünlü kullanım stratejisinin satın almaya yönlendirip yönlendirmediği araştırmada seçilen örnekleme göre farklılaşmaktadır. Farklı örneklemler üzerinde yapılan çalışmalarda satın alma davranışı konusunda farklı sonuçlara ulaşılmıştır. Bu stratejiyi sadece satış miktarını artırma amacıyla uygulayacak işletmelerin başarısı farklı değişkenlere bağlı kalacaktır. Ünlülerin ürün veya hizmeti satın alma davranışına etkisi sınırlıdır. İşletmeler ilk olarak bu stratejiyi uygulama amaçlarını belirlemeli, sonrasında hedef kitlelerine uygun bir ünlü ile çalışmalıdır.

\section{Kaynakça}

Çardaklı, S. (2008). Televizyon Reklamlarında Tanınmış Kişilerin Kullanılmasının Reklamın Hatırlanması Üzerindeki Etkisi Konusunda Bir Pilot Araştırma(Yüksek Lisans Tezi) Edirne: Trakya Üniversitesi Sosyal Bilimler Enstitüsü

Elden, M. (2016). Reklam ve Reklamcilı İstanbul: Say Yayınları

Erkal, E. (2013). Reklamlarda Ünlü Kullanımının "Satın Alma Davranışı" Üzerindeki Etkisi(Yüksek Lisans Tezi Konya: Selçuk Üniversitesi Sosyal Bilimler Enstitüsü

Ersavaş, S. (2007). Televizyon Reklamlarında Ünlü Kullanımı: 2005 Yılı Televizyon Reklamlarına Yönelik Bir İçerik Analizi (Yüksek Lisans Tezi) Eskişehir: Anadolu Üniversitesi Sosyal Bilimler Enstitüsü

İçli, G. ve Çopur, M. (2008). Pazarlama İletişiminde Renklerin Rolü. Trakya Üniversitesi Sosyal Bilimler Dergisi, 10(1)

İslamoğlu, A.H ve Alnıaçı, Ü. (2016). Sosyal Bilimlerde Araştırma Yöntemleri. İstanbul: Beta Yayıncilık

İşler, D. (2014). Televizyon Reklamlarında Ünlü Kişilerin Kullanılmasının Satın Alma Davranışlarına Etkisi: Cinsiyet Ekseninde Bir İnceleme. Süleyman Demirel Üniversitesi Vizyoner Dergisi 5(11) 
Odabaşı, Y. ve Oyman M. (2002). Pazarlama İletişimi Yöntemi. İstanbul: Media Cat

Pektaş, H. (1987). Reklam Nedir? İşlevi ve Etkileri Nelerdir?. Ondokuz Mayıs Üniversitesi Ĕ̆itim Fakültesi Dergisi 2

Solak, B. (2016). Televizyon Reklamlarında Ünlü Kullanımının Satın Alma Davranışı Üzerine Etkisi: Akdeniz İletişim Fakültesi Öğrencilerine Yönelik Araştırma. Gümüşhane Üniversitesi İletişim Fakültesi Elektronik Dergisi 4(1)

Şıker, P. ve Horzum, I. (2016). Televizyon Reklamlarında Yer Alan Ünlülerin Marka Farkındalığı Yaratmada Etkisi. Erciyes İletişim Dergisi 4(3)

Taşoğlu Paşalı, N. (2018). Pazarlama İletişimi. Ankara: Detay Yayıncılık

Uyar, A. (2018). Reklamlarda Ünlü Kullanımın Tüketiciler Açısından Değerlendirilmesi. Anemon Muş Alparslan Üniversitesi Sosyal Bilimler Dergisi 6

Uzunkaya, A. R. (2019). Üniversite Gençliğinin Alışveriş Tercihinde Star Kullanımın Rolü (Yüksek Lisans Tezi) İstanbul: T.C Maltepe Üniversitesi

http://sozluk.gov.tr/ Erişim Tarihi: 05.07.2019 